Received: August 20, 2017

Revision received: May 20, 2018

\title{
Research on the Current Situation of Law Teaching Mode and Reform Countermeasures
}

\author{
Gang Wang ${ }^{1}$ \\ Fuyang Normal College
}

\begin{abstract}
Firstly, the paper analyses the current situation of the three modes of law clinic, moot court and practical experience in law teaching, then puts forward some educational problems in the teaching mode, such as lack of knowledge relay, lack of characteristics in curriculum setting and weak sense of social identity, and finally puts forward the countermeasures in law teaching mode. It includes establishing a sound system structure, improving the evaluation system of law teaching mode and enhancing cooperation. This paper takes the teaching mode of law as the starting point, and puts forward the improvement countermeasures for the existing problems, hoping to provide help for the teaching method of law and the future employment situation.
\end{abstract}

\section{Keywords}

Law Teaching Mode $\bullet$ Curriculum $\bullet$ Countermeasures $\bullet$ Cooperation and Communication

\footnotetext{
${ }^{1}$ Correspondence to: Gang Wang (ML), College of Politics and Law, Fuyang Normal College, Fuyang 236037, China. Email: wanggang7299@163.com
} 
From 1996 to 2018, the teaching mode of law specialty has made rapid progress in quantity and quality of personnel as well as the way of education and its influence on society during the 20 years. In the design of University Law Course in our country, legal clinic mode, moot court mode, unit practice mode and case teaching mode are usually used to complete law teaching work (Dobrzykowski, Leuschner, Hong \& Roh, 2015).

\section{Legal clinic mode}

The model of legal clinic originated from American education curriculum, and has gradually entered the university curriculum teaching in China since the beginning of the new century. The inspiration of this teaching mode comes from the clinical experiments in medical clinics. It takes the classical cases as teaching objects. Under the guidance and help of teachers, students analyze and understand the cases by theoretical knowledge so as to achieve the purpose of learning for application.

In our university's curriculum teaching design, we use the "listening lecture" mode to complete the transmission of knowledge. Although this kind of teaching mode can transfer theoretical principles of law to students, due to the uniqueness and uncertainty of each case, it is difficult to combine the theoretical knowledge and case practice in practical operation. At the same time, this traditional teaching mode can not stimulate students' moral sentiment and professional honor to a greater extent.

Nevertheless, many universities in China can improve the teaching mode of law clinics to the greatest extent. Specifically, a legal aid clinic was established in a law school. The "doctors" in the clinic are students strictly selected after examinations. They handled all kinds of cases from telephone, Internet and clinic and provide kind help (Bie, Liu \& Xu, 2014). The improvement of this teaching mode not only enables students to combine theoretical knowledge with practical operation, but also improves students' judgment, emergency ability, professional identity and sense of honor.

\section{Moot court mode}

The moot court model takes the trial process in the actual court as a sample, adapts the real cases and presents them on the moot court. The difference between this mode and the legal clinic mode is that in the moot court only the process of litigation is "rehearsed", and the case is not authentic (Nafukho \& Irby, 2015). In the whole process of litigation, each student plays his/her own role, objectively and accurately states the doubts in the case, and completes the trial process as real as possible.

This moot court mode can maximize the advantages and disadvantages of students. Any mistake in the whole process may lead to the success or failure of litigation results. It can not only improve students' ability to response to emergencies, but also enhance students' sense of professional responsibility (Lin, 2018).

\section{Unit Practice Mode}

The unit practice mode mainly carries out practical training in prescribed time incourts, public security bureaus, law firms and procuratorates. The characteristics of this teaching mode are that different units focus on different nature of work, for example, trainees of the court often go out to perform tasks, while those in procuratorates often bring suspects to trial. In the whole internship process, trainees get in touch with real cases, 
in which meeting all kinds of personnel, writing case materials and discussing case content are inevitable. Such teaching mode has a far-reaching impact on students' knowledge mastery, application and moral cultivation (Jing \& Zhai, 2013).

\section{Analysis of Problems in Law Teaching}

Based on the current situation of law teaching mode and the results of literature review, this paper sums up problems in law teaching, namely, lack of knowledge relay, lack of characteristics in curriculum setting and weak social identity.

\section{Lack of knowledge relay}

The cultivation of "compound' talents in law teaching is an important goal and talents with all round abilities are more competent in specialized knowledge, professional ethics. They can make comprehensive use of the knowledge of various disciplines and solve the problems encountered in practice more professionally.

Specifically, in addition to professional knowledge of legal theory and practice, they should also be competent in culture, politics, economy, history studies and so on. The types of crimes in modern society have diversified characteristics, such as fraud on the Internet, exploitation of tax loopholes, economic effects caused by China's accession to the WTO and other cases, which are not only related to legal field (Jianwei, Jifang, Tao, Zhaohui \& Qingtuan, 2016). Therefore, "compound" talents are in urgent need, which puts higher requirements on legal workers.

Most students who study law think that other fields except their own major have little to do with themselves, and they do not understand the importance of "compound" talents. Some of them may be willing to learn more, but they don't know how to do it. This kind of "compound" learning is not only the superposition of knowledge, but also the improvement of technical ability, professional accomplishment, etc. Professional legal knowledge and experience on other fields are needed to solve problems in modern society. In view of the above problems of knowledge relay, the results of the survey on the compound knowledge of law students are shown in Figure 1, which are not optimistic (Ma, Guo \& University, 2016).

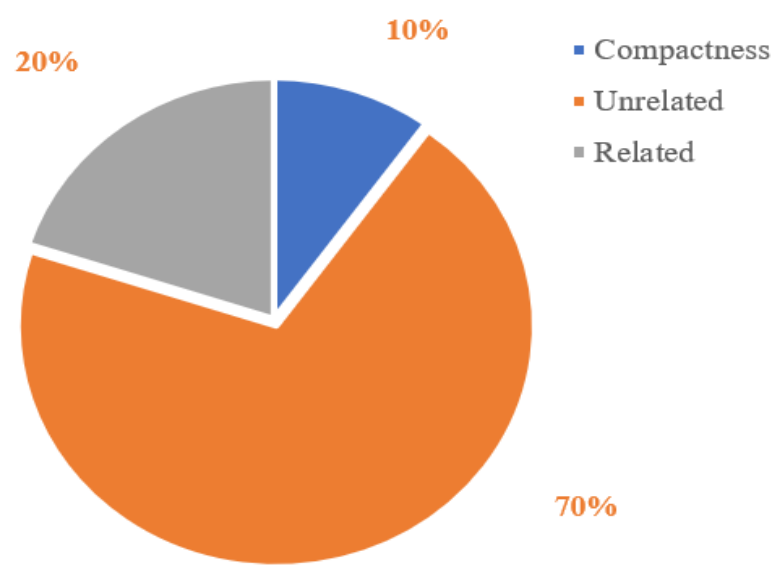

Figure 1. Investigation of compound knowledge in law students. 


\section{Lacking characteristics.}

At present, in the curriculum design of most colleges and universities have some problems in the teaching training, curriculum and teaching methods in all directions and links, which can not fundamentally solve the problem of the integration and effective use of knowledge of law majors during their study in Universities (Ren, Zheng \& Wu, 2016).

Taking the courses of the law major in Tsinghua University as an example, in addition to the basic introduction of law, the history of Chinese legal thought, the introduction of customary law and the traditional curriculum design of professional market management law, the discussion and case analysis of intellectual property law, and international trade law, there are few courses that can enable students to have practical operation. At the same time, in the allocation of teachers' resources, most of the instructors arranged in teaching are limited to the field of law, and the knowledge structure is single, which cannot provide students with pertinent opinions.

The lack of characteristics of this curriculum also reflects the obvious differences between the teaching methods and contents and the actual cases in the society. The cases in the textbooks are relatively old which do not keep up with the pace of the times. In the only case analysis courses, the form is more emphasized than the content, which is not different from the case analysis in traditional courses. Therefore, the design of practical courses and methods can not achieve satisfactory results. In Tsinghua University, a survey on the satisfaction of law students with curriculum design is shown in Figure 2. The results show that the lack of characteristics in curriculum design causes the problem of low satisfaction of students.

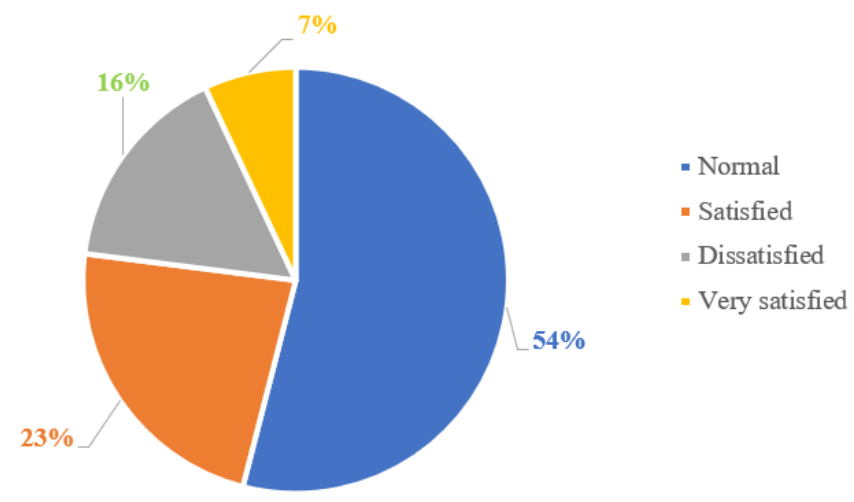

Figure 2. Investigation of compound knowledge in law students.

\section{Weak social identity}

In the designated training program of law teaching, the Ministry of Education, the College of the State Council and other institutions aim to train high-level, practical and compound law talents, and invest a huge amount of teaching sources to train students. Then in the field of social law, the lack of sufficient recognition 
of the legal talents trained by colleges and universities has led to the lack of trust in law students by government agencies, procuratorates and public security bureaus.

The orientation, learning content and future employment orientation of law majors are clearly demonstrated in the "Guidance and Training Program for Law Master Degree Postgraduates". The main destinations of graduates are judicial departments, legal service supervision departments and social public administration service departments (Yang \& Lin, 2016). Through the questionnaire survey of the personnel departments and some students of the above types of units, we can get a survey report of the employers' satisfaction with graduated law students, which are shown in Figure 3.

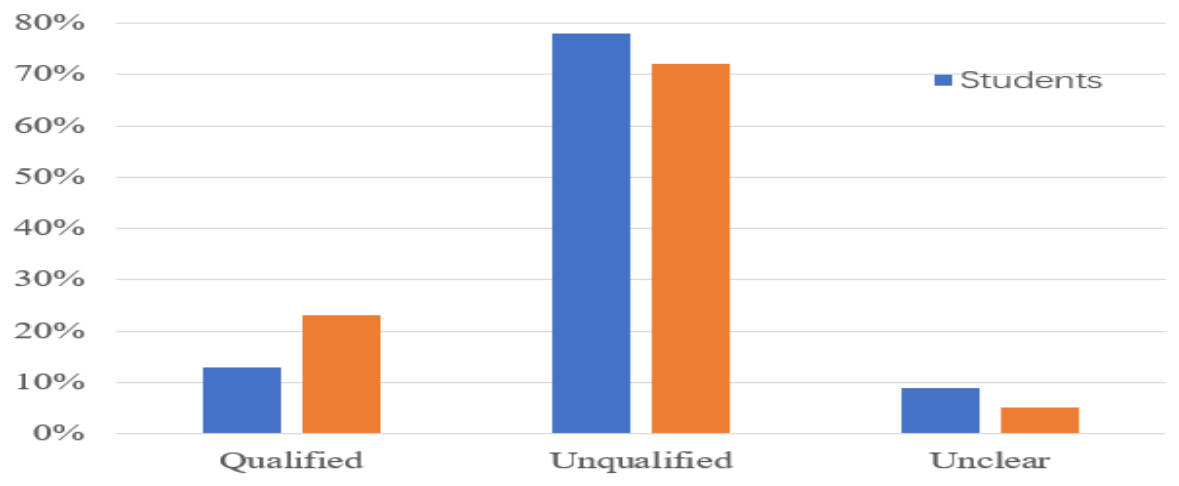

Figure 3. Satisfaction survey of graduate law students in employers.

Table 1

Law Graduate's Employment Table

\begin{tabular}{lcccccccc}
\hline University & $\begin{array}{c}\text { Study } \\
\text { abroad }\end{array}$ & $\begin{array}{c}\text { Government } \\
\text { agency }\end{array}$ & Institutions & $\begin{array}{c}\text { Judicial } \\
\text { system }\end{array}$ & Lawyer & Bank & Others & Total \\
\hline Peking & 21 & 33 & 51 & 16 & 8 & 5 & 16 & 150 \\
University & $14 \%$ & $22 \%$ & $34 \%$ & $11 \%$ & $5 \%$ & $3 \%$ & $11 \%$ & \\
Nankai & 2 & 21 & 24 & 9 & 4 & 5 & 15 & 78 \\
University & $3 \%$ & $26 \%$ & $30 \%$ & $11 \%$ & $5 \%$ & $6 \%$ & $19 \%$ & \\
Shandong & 1 & 9 & 11 & 8 & 7 & 9 & 13 & 57 \\
University & $2 \%$ & $16 \%$ & $19 \%$ & $14 \%$ & $12 \%$ & $15 \%$ & $22 \%$ & \\
Zhejiang & 9 & 21 & 28 & 16 & 11 & 10 & 7 & 102 \\
University & $9 \%$ & $21 \%$ & $27 \%$ & $15 \%$ & $11 \%$ & $10 \%$ & $7 \%$ & \\
Tsinghua & 9 & 21 & 14 & 18 & 8 & 11 & 15 & 96 \\
University & $9 \%$ & $22 \%$ & $15 \%$ & $19 \%$ & $8 \%$ & $11 \%$ & $16 \%$ & \\
Wuhan & 1 & 8 & 15 & 11 & 9 & 2 & 3 & 49 \\
University & $2 \%$ & $16 \%$ & $31 \%$ & $22 \%$ & $18 \%$ & $4 \%$ & $7 \%$ & \\
Sichuan & 10 & 17 & 22 & 26 & 16 & 12 & 10 & 113 \\
University & $9 \%$ & $15 \%$ & $19 \%$ & $23 \%$ & $14 \%$ & $11 \%$ & $9 \%$ & \\
\hline & & & & & & & & \\
\hline
\end{tabular}

In addition, from the employment situation of law graduates, we can also analyze the recognition degree of law students in society. This paper makes a statistical analysis on the employment units of law graduates in seven universities in the past five years. The proportion of those who can be employed in the legal service units, 
government administrative law enforcement units and real legislative units is not high, which also shows the serious employment situation of law graduates. The results are shown in Table 1.

According to the statistical results of Table 1, we can see that the proportion of graduates who can really engage in their own profession in the judicial system or the lawyer industry is about $30 \%$, while the proportion of those who choose to study abroad, enter government institutions and institutions accounts for more than $50 \%$, which fully illustrates the professional skills of law graduates is not commonly recognized in society (Leopoldo, Daniel \& Jose, 2011).

\section{Reform Countermeasure Analysis}

In view of the above problems existing in the teaching mode of law, the paper makes suggestions from three aspects: establishing a sound system, improving the evaluation system of the teaching mode of law and broadening the way of cooperation and communication so that to inspire teachers, students and staff in the teaching of law.

\section{Establish a sound system of National JM Education Steering Committee}

National JM Education Steering Committee is composed of experts and scholars from law research institutions, universities, management teams and Central Judicial units. Its main tasks are to train students, clarify curriculum settings, select teaching materials and case databases, establish standards and norms, etc.

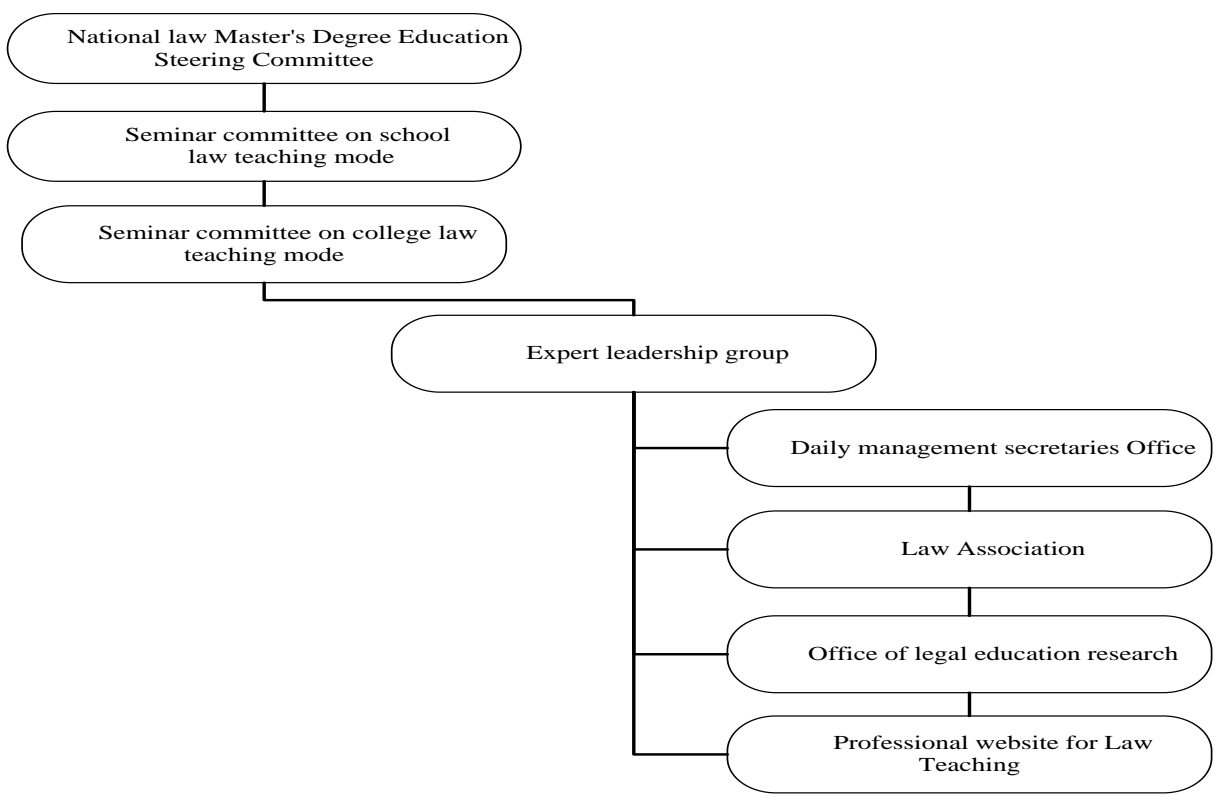

Figure 4. Perfect system diagram on National law Master's Degree Education Steering Committee. 
Wang / Research on the Current Situation of Law Teaching Mode and Reform Countermeasures.

Therefore, National JM Education Steering Committee plays a decisive guiding role in law teaching. It can not only implement the latest policies and guidelines, but also play a macro-guiding role for teachers, students and law workers in society. At the same time, it can provide information sharing and exchange for law courses in Colleges and universities (Liao, Wu, Hu \& Tsui, 2010). Specifically, if we want to establish a sound system, we should establish a clear organizational system and a perfect division of responsibilities for all units from top to bottom: under the guidance of the committee, we should set up a seminar committee on legal teaching mode at school and college levels to take macro-control; experts with strong professional skills and advanced teaching concepts set up full-time expert leadership group; finally, in each department, a specific law teaching daily management secretarial group office, a law teaching research subject office, law association with students as the main body, and a website connect to the outside of the school are set up. The complete system is shown in Figure 4.

\section{Improve the evaluation system of law teaching mode.}

The evaluation system determines the quality of the teaching, and plays a decisive role in promoting the healthy and steady development of the teaching. With the popularization of higher education and the enlargement of the scale of education, the curricula of colleges and universities setting up under the guidance of National JM Education Steering Committee are more diversified. Therefore, the evaluation system and standards are not uniform, resulting gaps between the education quality of those colleges and universities. Therefore, it is particularly important to improve the evaluation system of teaching mode.

Strictly examine the qualifications of colleges and universities Schools with law majors have expanded from 8 universities at the beginning to nearly 80 colleges and universities now, which may be due to the progress in national policies and the times. However, there are great differences in the faculty construction and personnel training among the universities. One of the important reasons is the opaque and irregular bidding process. Therefore, it is necessary to set up an evaluation institution strictly, to examine the curriculum, teaching methods and qualification of colleges and universities according to the standards, and to examine the quality and quantity of law books in the moot court operating room and libraries and the qualifications of the teachers in colleges and universities so as to achieve the goal of training talents in all aspects.

Improve the self-assessment system In the teaching of law, in addition to the regular rules and regulations and requirements, students and staff in the school's legal system should be randomly assessed annually, semiannually and quarterly. Students' examination results, teachers' scientific research achievements, staff rewards, promotion and even punishment should be announced in time so that all relevant personnel can get a sense of participation. In addition, the contents of annual enrollment, graduation, thesis and major activities of law specialty should be reported in various forms, and the evaluation system of law teaching mode should be improved from various angles.

\section{Widening the mode of cooperation and communication}

Law education is a solemn traditional subject. Besides the traditional teaching methods and the forms of cooperation and exchange, widening the train of thought, opening up more ways and methods to enrich the 
teaching mode are needed. The method of "inviting in and going out" should be used to allow more experts from home and abroad to enter schools, disseminating the latest ideas and methods, broadening the horizons of teachers and students in schools. Moreover, we should dare to share our own achievements with brother colleges and professions and promote the methods and models of law teaching, so that to achieve the goal of common prosperity and progress.

\section{Conclusion}

The purpose of the research on the teaching mode of law is to improve the healthy development of the field of law. Although some achievements have been made in the current teaching modes of law clinics, moot courts and unit practice, there are still some problems in education, such as lack of knowledge delay, lack of characteristics in curriculum setting and weak sense of social identity. Problems cannot be solved by complaining or ignoring. Therefore, the paper puts forward some countermeasures, such as establishing a sound system for National JM Education Steering Committee, perfecting the evaluation system of law teaching mode and broadening the way of cooperation and communication. Even though there is still a long way to go. I hope that through my own efforts, I can offer advice and suggestions for the cause of law teaching, promote the healthy development of law in the future, and provide help and support for the employment of graduates.

\section{References}

Bie, M., Liu, D. C., \& Xu, Y. X. (2014). The use of information technology to promote professional development: Studies in teacher education. In Applied Mechanics and Materials, 568, 1955-1958. http://dx.doi. org/10.4028/www.scientific.net/AMM.568-570.1955

Dobrzykowski, D. D., Leuschner, R., Hong, P. C., \& Roh, J. J. (2015). Examining absorptive capacity in supply chains: Linking responsive strategy and firm performance. Journal of Supply Chain Management, 51(4), 328. http://dx.doi. org/ 10.1111/jscm.12085

Jianwei, Z., Jifang, Z., Tao, C., Zhaohui, L., \& Qingtuan, L. (2016, December). Exploration of the innovative medical talent training based on problem-based learning in digital image processing teaching. In Information Technology in Medicine and Education (ITME), 2016 8th International Conference, 163-167. IEEE.

Jing, X., \& Zhai, R. (2013, April). Exploration on innovative practice teaching of Digital Image Processing for Agricultural colleges. In Computer Science \& Education (ICCSE), 2013 8th International Conference, 991994. IEEE.

Leopoldo, L. C., Daniel, S. S., \& Jose, L. G. (2011). Innovative and absorptive capacity of international knowledge: An empirical analysis of productivity sources in Latin American countries. Latin American Business Review, 12(4), 309-335. http://dx.doi. org/10.1080/10978526.2011.633031

Liao, S. H., Wu, C. C., Hu, D. C., \& Tsui, K. A. (2010). Relationships between knowledge acquisition, absorptive capacity and innovation capability: An empirical study on Taiwan's financial and manufacturing industries. Journal of Information Science, 36(1), 19-35. http://dx.doi. org/10.1177/0165551509340362 
Wang / Research on the Current Situation of Law Teaching Mode and Reform Countermeasures.

Lin, L. Y. (2018, August). Exploration on Innovative Teaching and Information Technology Integration in College Physical Education. In International Conference on Innovative Technologies and Learning, 640647. Springer, Cham.

Ma, Y., Guo, J., \& University, S. A. (2016). Digital electronic technology teaching method innovative exploration and practice. China Modern Educational Equipment.

Nafukho, F. M., \& Irby, B. J. (2015). Handbook of research on innovative technology integration in higher education. IGI Global

Ren, Y., Zheng, X., \& Wu, M. (2016). Promoting the integration and innovation of information technology with education__ interpretation of china's 13th five-year plan for ICT in education. Modern Distance Education Research.

Yang, X., \& Lin, J. (2016). Innovation and integration, pushing the advertising industry towards the new development path in china: analysis of the 13th five-year plan of advertising industry. Advertising Panorama, 